The Barbados, Antigua, and Trinidid rainfalls have beer șubjected to the same treatment with the same results; but it will be noticed in the following table that the smoothed Jamaica rainfall rises and falls with much greater regularity than the smoothed rainfall in Barbados, Antigua, and Trinidad; the irregularity in the last island is due to the circumstance that we are dealing with the rainfall at one station only, namely the Botanic Gardens, instead of the rainfall deduced from many stations, as in the other islands.

\section{ON PREPARING THE WAY FOR TECHNICAL} INSTRUCTION.

SIR PHILIP MAGNUS discoursed on methods of tech nical instruction on February 14 , at the College of Preceptors. In the course of his address he pointed out that our intermediate schools were generally described as in a state of chaos, and it could scarcely be expected that so nebulous a system would be largely influenced by the definite movement in

\begin{tabular}{|c|c|c|c|c|c|c|c|c|c|}
\hline \multirow{2}{*}{$\begin{array}{c}\text { Year } \\
\text { (middle } \\
\text { of). }\end{array}$} & \multirow{2}{*}{$\begin{array}{c}\text { Sun- } \\
\text { spot } \\
\text { period. }\end{array}$} & \multicolumn{2}{|c|}{ JAMAICA. } & \multicolumn{2}{|c|}{ BarbaLOS. } & \multicolumn{2}{|c|}{ Antigua. } & \multicolumn{2}{|c|}{ TrINIDAD. } \\
\hline & & $\begin{array}{l}\text { Rainfall, } \\
\text { go stations. }\end{array}$ & $\begin{array}{l}\text { Average } \\
\text { for } 3 \text { years. }\end{array}$ & $\begin{array}{l}\text { Rainfall, } \\
\text { go stations. }\end{array}$ & $\begin{array}{c}\text { Average } \\
\text { for } 3 \text { years. }\end{array}$ & $\begin{array}{l}\text { Rainfall, } \\
47 \text { stations. }\end{array}$ & $\begin{array}{c}\text { Average } \\
\text { for } 3 \text { years. }\end{array}$ & $\begin{array}{l}\text { Rainfall, } \\
\text { I station. }\end{array}$ & $\begin{array}{c}\text { Average } \\
\text { for } 3 \text { years. }\end{array}$ \\
\hline $\begin{array}{r}1843 \\
44 \\
45 \\
46 \\
47 \\
48 \\
49 \\
50 \\
51 \\
52 \\
53 \\
54 \\
55 \\
56 \\
57 \\
58 \\
59 \\
60 \\
61 \\
62 \\
63 \\
64 \\
65 \\
66 \\
67 \\
68 \\
69 \\
70 \\
71 \\
72 \\
73 \\
73 \\
74 \\
75 \\
76 \\
77 \\
78 \\
79 \\
80 \\
81 \\
82 \\
83 \\
84 \\
85 \\
86 \\
87 \\
88 \\
89 \\
90 \\
91 \\
1892\end{array}$ & Max. & $\begin{array}{l}53 \cdot 65 \\
64 \cdot 47 \\
67 \cdot 74 \\
55 \cdot 37 \\
89 \cdot 43 \\
50 \cdot 09 \\
45 \cdot 18 \\
63 \cdot 06 \\
68 \cdot 94 \\
52 \cdot 42 \\
71 \cdot 35 \\
68 \cdot 40 \\
76 \cdot 42 \\
88 \cdot 84 \\
55 \cdot 44 \\
68 \cdot 60 \\
57 \cdot 87 \\
59 \cdot 26 \\
56 \cdot 90 \\
59 \cdot 86 \\
90 \cdot 61 \\
70 \cdot 66 \\
72 \cdot 11 \\
74 \cdot 15 \\
64 \cdot 42 \\
84 \cdot 70 \\
72 \cdot 98\end{array}$ & $\begin{array}{l}61 \cdot 95 \\
62 \cdot 53 \\
70 \cdot 85 \mathrm{Max} . \\
64 \cdot 96 \\
61 \cdot 57 \\
52 \cdot 78 \mathrm{Min} . \\
59 \cdot 06 \\
61 \cdot 47 \\
64 \cdot 24 \\
64 \cdot 06 \\
72 \cdot 06 \\
77 \cdot 89 \mathrm{Max} . \\
73 \cdot 57 \\
70 \cdot 96 \\
60 \cdot 64 \\
61 \cdot 91 \\
58 \cdot 01 \\
58 \cdot 67 \mathrm{Min} . \\
69 \cdot 12 \\
73 \cdot 71 \\
77 \cdot 79 \mathrm{Max} . \\
72 \cdot 3 \mathrm{I} \\
70 \cdot 23 \\
74 \cdot 42 \\
7403 \\
-1\end{array}$ & $\begin{array}{l}\text { in. } \\
45 \cdot 31 \\
74 \cdot 45 \\
43 \cdot 91 \\
65 \cdot 82 \\
48 \cdot 10 \\
63 \cdot 77 \\
52 \cdot 77 \\
67 \cdot 88 \\
59 \cdot 40 \\
58 \cdot 77 \\
68 \cdot 84 \\
50 \cdot 88 \\
77 \cdot 31 \\
48 \cdot 49 \\
6090 \\
45 \cdot 22 \\
54 \cdot 22 \\
57 \cdot 91 \\
73 \cdot 82 \\
59 \cdot 27 \\
42 \cdot 38 \\
59 \cdot 19 \\
68 \cdot 64 \\
59 \cdot 68 \\
69 \cdot 93 \\
44 \cdot 60 \\
48 \cdot 52 \\
60 \cdot 17 \\
41 \cdot 46 \\
48 \cdot 55 \\
51 \cdot 69 \\
59 \cdot 22 \\
61 \cdot 71 \\
52 \cdot 73 \\
74 \cdot 10 \\
73 \cdot 10 \\
74 \cdot 30 \\
70 \cdot 98 \\
70 \cdot 45 \\
50 \cdot 06 \\
63 \cdot 12 \\
57 \cdot 95 \\
44 \cdot 08 \\
82 \cdot 81 \\
69 \cdot 1 \\
69 \cdot 09 \\
76 \cdot 92 \\
52 \cdot 53 \\
66 \cdot 30 \\
-1\end{array}$ & 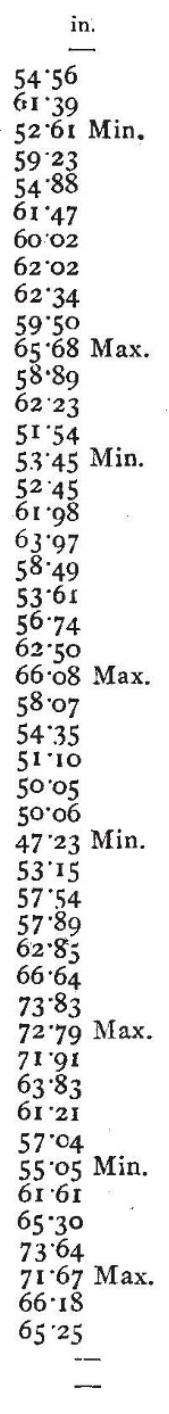 & $\begin{array}{l}31 \cdot 16 \\
28 \cdot 78 \\
41 \cdot 98 \\
49 \cdot 05 \\
47 \cdot 11 \\
61 \cdot 50 \\
49 \cdot 69 \\
53 \cdot 75 \\
33 \cdot 04 \\
55 \cdot 51 \\
43 \cdot 98 \\
43 \cdot 39 \\
47 \cdot 78 \\
43 \cdot 68 \\
44 \cdot 23 \\
73 \cdot 59 \\
33 \cdot 00 \\
50 \cdot 01 \\
38 \cdot 53\end{array}$ & 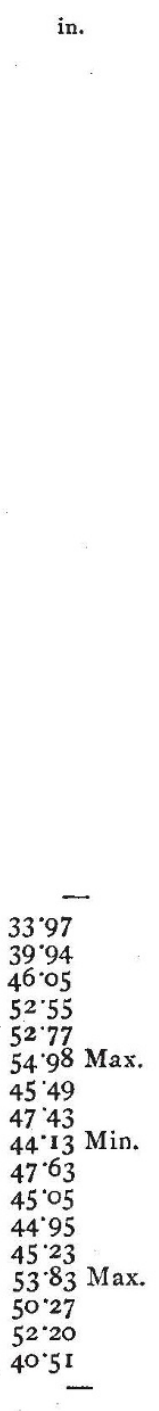 & $\begin{array}{l} \\
\\
63 \cdot 15 \\
66 \cdot 80 \\
62 \cdot 90 \\
85 \cdot 28 \\
67 \cdot 86 \\
66 \cdot 56 \\
56 \cdot 21 \\
53 \cdot 46 \\
69 \cdot 35 \\
75 \cdot 58 \\
49 \cdot 95 \\
44 \cdot 02 \\
76 \cdot 28 \\
60 \cdot 90 \\
81 \cdot 95 \\
72 \cdot 10 \\
61 \cdot 24 \\
65 \cdot 43 \\
82 \cdot 34 \\
65 \cdot 72 \\
52.99 \\
70 \cdot 50 \\
56 \cdot 88 \\
43 \cdot 22 \\
86 \cdot 82 \\
64 \cdot 09 \\
65 \cdot 44 \\
73 \cdot 79 \\
82 \cdot 90 \\
53.74 \\
91 \cdot 14\end{array}$ & $\begin{array}{l} \\
\\
\\
\\
64 \cdot 28 \\
71 \cdot 66 \\
72 \cdot 01 \mathrm{Max} . \\
73 \cdot 23 \\
63 \cdot 54 \\
58 \cdot 74 \\
59 \cdot 67 \\
66 \cdot 13 \\
64 \cdot 96 \\
56 \cdot 52 \\
56 \cdot 75 \mathrm{Min} . \\
60 \cdot 40 \\
73 \cdot 04 \\
71 \cdot 65 \\
71 \cdot 43 \\
66 \cdot 26 \\
69 \cdot 67 \\
71 \cdot 16 ? \\
67 \cdot 02 \\
63 \cdot 07 \\
60 \cdot 12 \\
56 \cdot 87 \mathrm{Min} . \\
62 \cdot 31 \\
64 \cdot 71 \\
72 \cdot 12 \\
67 \cdot 77 \\
74 \cdot 04 \\
70 \cdot 14 \\
75 \cdot 93 \\
\end{array}$ \\
\hline
\end{tabular}

The Barbados rainfall was discussed by Sir Rawson W. Rawson in $1873,{ }^{1}$ and indeed it neither was, nor yet is easy to make out the connection between the years 1843 and 1863 ; but since 1863 it is all plain sailing, especially when aided by Jamaica on one side and Antigua on the other.

I have written to Mr. 'Hart, the superintendent of the Botanic Gardens, Trinidad, asking him to assist me in getting the Trinidad rainfall into better form.

Maxwell Hall.

I NAtURB, vol. viii. pp. 245,547 ; vol. x. p. 263 ; and vol. xi. p. 327 . No. 1269 , vol. 49$]$ favour of technical education. As a fact, they had been much less affected than the institutions ahove and below them, and probably in consequence of the recognised absence of organisation. It might be that the Royal Commission about to be appointed would introduce order into this chaos, and that when each school knew exactly its position in the school hierarchyits relation to the schools above and below it, and the special and particular purpose it was required to serve-our intermediate schools, both first and second grade, would become more efficient than they now were in preparing the way for that 
technical education which, in every branch of professional and commercial life, was heing recognised as indispensable.

In the New Education, the most important subject of instruction was science. It was the development of science, and its application to the varied work of life, that had changed to a great extent, and would chanye still more in the near future, the entire character of our school teaching. In an address given in 1876, Sir Philip remarked upon the inadequate attention given to the teaching of science in our endowed schools. Out of one hundred and twenty-eight schools which furnished replies to the Commissioners at that time, there were only sixtythree schools in which any kind of science was taught, and of these only thirty devoted any regular time to scientific study. Since then a great change had taken place; but the change was more marked in the elementary than in the secondary schools. And the right of science to be included in the school curriculum had only recently been generally recognised.

The advance was very satisfactory ; but the important ques. tion was whether, with the increase in the number of schools in which science was taught, there had been any corresponding improvement in the melhod of science teaching?

The progress in this direction bad not been as marked as one might have wished. The correct methods of science teach ing were only very gradually being understood. It was largely owing to the usefulness of the information which the study of science involved, that the value of the study as a means of education had been lost sight of. It should be remembered that "acquirement of every kind has two values-value as knowledge and value as discipline"; and, in early education, the latter was by far the more important. With the first feeling of intoxication which the breathing of the atmosphere of science excited, there was a strıng reaction against the teaching of subects apparently useless, as mere instruments for mental gymnastics. There was a loud cry for useful information; and the scientific lecture, with its platform experiments, served both to awaken the interest of the pupil and to afford such information. But, grariually, better views prevailed, and it was recognised, although very slowly, that information was not the first object of science teaching, and that, valuable as was the information which science conveyed, such inlormation was of little use unless the process of inforning served to train and discipline and educate the faculties. Accuracy in thought and expression, the power of arranging and co-rrdinating facis, and of acquiring, relaining, and reproducing in logical order, new irleas, and the hatiot of deliberation in arriving at conclusions, were educational ends of far more real value than any amount of mere knowledge which the student of science might gain. The recognition of this educational truth had rudely shaken methods of teaching, and even of examining in scientific subjects.

Herbert Spencer, in his well-known essays on Education, had said :- "It would be utterly contrary to the beautilul economy of nalure if one kind of culture were needed for the gaining of information, and another kind were needed for mental gymnastics. Everywhere throughout creation we find faculties developed ihrough the perforinance of those functions which it is their office to perform; not through the performance of artificial exercises devised to fit them for those functions. The education of most value for guidance must at the same time be the education of most value for discipline." The method of teaching science must therefore be carefully considered, so that the training of the faculties might be steadily kept in view as the aim and object of the instruction, rather than the mere acquisition of hnowledge. This change of method involved the substitution, from the very commencement, of practical work on the part of the pupil for the ordinary lecture or lesson.

At the outset, the practical exercises should he of the very simplest kind. The pupil must take nothing for granted. It was clear, therefore, that he must commence with simple exercises in measur ement. In physics they were always dealing with quantities, an 1 could not understand what is meant by a quantity except by measuring it. The first measurements to be matle were those of length. In making such measurement, certain standards had to be considered, and different systems (the English and the metric systems) should be compared. These comparisons involved easy exercises in arthmetic, which might be practised in connection with such concrete examples. Various objects should the actually measured, and the length calculated by multiplication or division of other measurements. But the pupil should be made thoroughly familiar with his standard of measurement hefure passing away from this exercise. This should be followed by measurement of areas, the consideration of which was fruitful in useful exercises. In country schools the actual measurement of the areas of fields, by simple methods of surveying, might be usefully attempted; in town schools there was generally a playground which would afford opportunities for similar exercises. Then the methods and results of all such measurements should be carefully and neatly transferred to paper, and the pupil should be thus incidentally exercised in elementary drawing. The measurement of volume would follow, with more varied and more difficult problems.

Immediately connected with the measurement of volume was that of mass. There, of course, a difficulty arose, owing to the close connection between mass and weight, and the difficulty of distinguishing between them. But the explanation of this difficulty might be postponed, and the pupil could be allowed to use ordinary weights as measures of mass. At this stage he was in troduced to a balance, and, with a view of inducing habits of accuracy, he should at once use a fairly good balance. The exercises were very numerous which the pupil could practise with a good pair of scales. From this point the order of any elemen. tary series of lessons could be varied at the discretion of the teacher. The balance suggested experiments, to be done by the pupil, on the use of the lever, whence the principle of the lever could be obtained. From the common halance to the Roman balance, and to other modes of weighing, the steps were very gradual. The relative volumes of bodies of the same material could then be ascertained by the balance, and former exercises in measurement be verified and repeated. The pupil should not only do the actual work himself, but should write out clearly a description of what he had done, thus learning to connect action, thought, and words. From these exercises the pupil might pass to the consideration of the difference in homogeneous hodies of the same volume and of different weight, and so on, by very easy stages, to methods of ascertaining relative weights of different substances. Exercises in finding specific gravities of solids, powders, and liquids, gave opportunity for very valuable instruction, and prepared the way for the use of instruments of precision, and for knowldege of interesting properties of different kinds of bodies. The value of these lessons consisted in the accuracy of measurement, and in the clearness and correct ness of the written record, as regards the statement of facts, the sequence of reasoning, the numerical calculations, and the use of wurds and phrases.

It was, of course, essential that these written exercises should be carefully corrected, as are exercises in Latin or Greek composition. The aim of the instructor, in compiling such an introductory course as that suggested, should be to include those subjects, an acquaintance with which was required to enter upon the systematic study of any one branch of science, and which were practically common to all branches. The character of an introductury cuurse might be influenced by the consideration of the special science which, in any particular school or district, would be likely to be studied, or indeed by the special taste of the instructor. A knowledge of the use of simple measuring instruments, including the thermometer, the barometer, the hygrometer, having been acquired, the pupil might pass by cai efully suggested experimenis to the determination of simple physical laws, and to the discovery of the composition of common substances, such as air, water, salt, lime, \&c. ; and it was needless to say that such exercises would open up wide views of the elementary facts and laws of different branches of science, and would prepare the way for the specialised teaching which more properly belongs to technical education.

\section{UNIVERSITY AND EDUCATIONAL INTELLIGENCE.}

OXFORD.-Prof. August Weismann will deliver the Romanes Lecture in the Skeldonian Theatre, on Wednesday, May 2.

Pruf. H. H. Turner has selected "The International Photographic Chart of the Heavens" for the subject of his inaugural lecture as Savilian professor of astronouny, to be delivered to-morrow.

CAMBridge. - The Vice-Chancellor has appointed Mr. J. W. Clark, Registrary and formerly Superintendent of the Museum of Zoulogy, to the office of Reader on Sir Robert Rede's toundation for the present year, in succession to Prof. Foster.

The Special Board for Medicine report that in consequence of the great increase in the number of candidat es for the M.B. degree (in 1893 there were 224 to be examined), it is necessary to increase the staff of Examiners to four in Medicine and four in Surgery.

No. I 269 , voL. 49] 